\title{
Proposed framework for potential religious tourism destination in Cagayan Valley Region
}

Tao-Ing, Reymar C. \

Lyceum of the Philippines University Batangas, Philippines (mark19_taoing@yahoo.com)

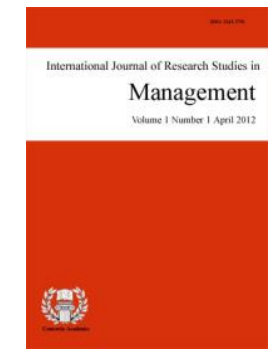

ISSN: 2243-7770 Online ISSN: 2243-7789

OPEN ACCESS

\section{Abstract}

This study aimed to propose a framework for religious sites improvement in Cagayan Valley Region. The researcher determined the motivational factor, tourist experiences and assessed the tourist behavior and intention to revisit the religious sites in Cagayan Valley Region. It tested the significant difference when grouped according to demographic and psychographic profiles of the respondents and determined the significant relationship among the given variables. The researcher used quantitative method and descriptive research design. The respondents of the study were 417 tourists who visited the religious sites. The instrument was adapted from three different studies. Further, the Statistical test used for the study was based on the Shapiro Wilk test, Kruskal Wallis Test, Mann Whitney U-test to test the significant differences while, Spearman Rho for the test of relationship, then Linear regression to determine the predictor variables of tourist experience, tourist intention and tourist motivation. The study concluded that majority of the respondents are female, aged 25 years old and below or belonging to generation $\mathrm{Z}$ and single. The respondents visited the religious sites to discover new cultures and different religions and stayed for 2-4 days. They are excellently satisfied because of the sacredness of the ambience, availability of facilities and accessibility of the prayer area. Moreover, locals are friendly and respectful. Lastly, the research paper proposed a framework and provide relevant recommendations.

Keywords: potential destination, religious tourism, destination framework, Philippines, Cagayan Valley 


\section{Proposed framework for potential religious tourism destination in Cagayan Valley Region}

\section{Introduction}

For several years, religious tourism has flourished and is distinct from other forms of tourism. It encompasses pilgrimage, sightseeing, traveling, and visiting different places with a touch of the religious aspect. It takes place in a particular geographical area that forms part of a widely known cultural landscape. The complexity of the elements of the destination, its space's existence dictates its diversity and shape, which is the result of changes in tourists' inspiration, behaviors, and wishes (Aulet \& Duda, 2020). Religious tourism the accessibility of the place really matters to many tourists, the place where they could stay, the price and the popularity of the place and events as well (Giușcă et al., 2018).

Sacred spaces can be global, where visitors are exposed to the universally held belief in religiousness as a way of life (Nieminen, 2012). Space and religious environment, such as holy places, are significant parts of religious tourism since they provide a topic of interest for visitors and pilgrims (Duda \& Doburzyski, 2019). The religious significance is associated with the religious values, time and events being set by the religious organization. In the context of religious tourism, facilities, tourist activities and services are essential (Aulet \& Duda, 2020). As a result, many people seek religiously invigorating spiritual and cultural experiences in order to grow and be enlightened by what they discover at a location (Nicolaides, 2016).

Motivations, on the other hand, might arise from the expectation of an emotional experience. Furthermore, motivation might shift as a person transitions activities, such as from pilgrim to tourist or vice versa, frequently without the person being aware of the shift (Blackwell, 2010). The religious sites cannot stand alone as a tourist destination, there must be other factors that will help or sustain the religious site as to become a tourist destination (Shen et al. 2019). A sacred place's efficacy in the geographical and traveler space is also greatly influenced by its value in pilgrims' religious or social consciousness. Its location, connection, and administration of pilgrimage and tourism activities may be critical, and in many cases determining, factors in the object's attraction (Olsen, 2019) and religious product authenticity (Muriuki et al., 2016).

Religion II is the Cagayan Valley Region, strategically placed on mainland Luzon's northeastern coast. The Cordillera Mountain range borders it on the west, the Sierra Madre on the east, the Caraballo Mountains on the south, and the Luzon Strait on the north. Cagayan Valley is one of the Philippines' locations that makes visitors fall in love with the country's natural beauty. Cagayan Valley Region is undoubtedly a one-stop destination for travelers looking for a magnificent view and unforgettable experience, with a cold fresh air, calming blue seas, breath taking waterfalls and caves, green forests, and many vintage-old historical landmarks and exciting festivals (Department of Trade and Industry, 2021). Meanwhile, sightseeing, visits, vacations, and pilgrimages were the most common forms of tourism in the region. Other types of tourist packages, such as adventure and sports tourism, are still missing, among other things (Neda, 2013).

The Cagayan Valley Region is home to several religious tourism attractions, yet there is a clear research gap in this area (Rebuya et al., 2020). To close this gap, the study will establish a recommended framework for religious sites sustainability and growth in the region, considering tourists' perceptions. The researcher is deeply motivated in conducting the study to create an improvement and authenticity drive religious branding initiatives in Region II. This research will highlight the areas to sustain and improve from the inputs of tourists' intention, factors that motivate and help them to decide in visiting the religious site, upon arrival to the destination will take consideration the essential elements that contribute to their memorable and meaningful experience. In this case, the paper addresses the different aspects to improve the religious features and characteristics as to become a promising religious destination. The researcher believes that will help to stablish religious destination branding

2 Consortia Academia Publishing (A Partner of Tourism Educators and Movers of the Philippines) 
the Cagayan Valley Region.

\subsection{Objectives of the Study}

This study aimed to develop a framework for religious sites in Cagayan Valley Region from the inputs of tourist motivation, experiences, and revisit intention. More specifically, it aimed to; 1) present the psychographic profile of the respondents in terms of: willingness to visit again, recommend for others to come and overall satisfaction; 2) determine the motivational factor visiting the religious sites in Cagayan Valley Region in terms of cultural and historic motives, spiritual and religious motives, fun and social contact, nature and wellness and healing; 3) analyze the tourist experiences visiting religious sites in Cagayan Valley Region in terms of: religious attributes, emotional involvement and overall satisfaction; 4) assess the tourist behavior and intention to revisit the religious sites in Cagayan Valley Region as relate to social environment, religious sites facilities, food and beverage, service quality, locals' behavior and religious site tourist's revisit intentions; 5) test the significant difference when grouped according to satisfaction; 6) test the significant relationship among the three given variables; and 7) propose a framework for religious sites in Cagayan Valley Region.

\section{Methods}

\subsection{Research Design}

The researcher used qualitative-descriptive research design using survey method. According to Siedlecki (2020), the descriptive research design described the details and characteristics of the population or phenomenon that is being considered. This design is the most appropriate since the study involves the description of the variables like the local residents' motivations for religious tourism attractions, behavioral intention of local residents to visit religious sites, and access to and use of pilgrimage sites in the region. Moreover, the researcher utilized adapted various questionnaires from previously conducted studies both local and foreign.

\subsection{Participants}

The respondents of the study were 417 tourists who visited the religious sites in Region II. These tourists helped to identify the strong and weak areas of the religious sites and other elements of the destination. The number of participants was computed through Raosoft calculator which gained the result is 385 tourists with the margin of error of $5 \%$ and confidence level of $95 \%$ of total tourist arrival in Cagayan Valley Region.

\subsection{Instrument}

The instrument was adapted from three different studies. It is divided with four parts; the first part helped to establish the demographic profile of the respondents in terms of gender, age, and marital status, the second part focused on the psychographic profile relatively to the purpose of visit in Cagayan Valley Region, length of visit, willingness to visit Cagayan Valley Region, recommend to others to come and over-all satisfaction. The third part is one of the cores of the study focusing on the assessment on the motivational factor visiting the religious sites in Cagayan Valley Region in terms of spiritual and religious motives, cultural and historic motives, wellness and healing, nature, fun and social contact (Rybina \& Lee, 2021).

The fourth part determined the tourist experiences visiting religious sites in terms of tourist motivation to visit religious sites in Cagayan Valley Region in terms of: religious attributes, emotional involvement and overall satisfaction (Apritado \& Borbon 2021); and the last analyzed the tourist behavior and intention to revisit the religious sites in Cagayan Valley Region as relate to social environment, religious sites facilities, food and beverage, service quality, locals' behavior and religious site tourist's revisit intentions (Hanafiah, et al., 2021).

The reliability test result for the Tourist Behavior and Intention obtained a Cronbach's alpha value of 0.959 
Tao-Ing, R. C.

which signifies that the questionnaire has an excellent internal consistency. Meanwhile, the instrument for identifying the Tourist Motivation obtained a Cronbach's alpha value of 0.981 which implies that the instrument has an excellent internal consistency as well as the instrument for identifying tourist experiences with 0.987 . Aside from pilot testing the researcher able to consult some experts to validate the adapted questionnaire.

\subsection{Data Gathering Procedure}

The questionnaire was administered through Online Google form survey by sending link to Facebook Messenger application and via email. Some were distributed directly to the respondents since the researcher got a chance to interact with the tourists as he visited the actual place. Upon retrieval of the data it was tabulated, interpreted, analyzed, and presented.

\subsection{Data Analysis}

The study was non-parametric, likewise, the statistical test applied was non-parametric. The nature of data is not normally distributed based on the Shapiro Wilk test with p-value of less 0.01 . Therefore, Kruskal Wallis Test was used to calculate the differences of variables with three or more categories while Mann Whitney U-test was used to test the differences of variable with two categories. For the test of relationship, Spearman Rho was used using 0.05 alpha level. Linear regression was also used to determine the predictor variables of tourist experience as dependent variable from tourist intention and tourist motivation as independent variables.

\subsection{Ethical Considerations}

Before the circulation of questionnaires, the researcher informed the respondents about the nature of the study and will clarify the purpose and objectives of the study. The consensus of the respondents was humbly sought. The researcher assured them of the utmost privacy of their identities. Respecting the respondents' thoughts and perspectives, as well as recoding their suggestions on the research issue, assured the successful of the study.

\section{Results and Discussion}

\section{Table 1}

Psychographic profile of the respondents

\begin{tabular}{lccc}
\hline \multicolumn{1}{c}{ Profile } & Categories & Frequency & Percentage \\
\hline Willingness to Visit & Yes & 337 & 80.8 \\
Cagayan Valley Region & Maybe & 78 & 18.7 \\
Again & Never & 2 & .5 \\
\hline Recommend for Others to & Yes & 355 & 85.1 \\
Come & Maybe & 61 & 14.6 \\
& Never & 1 & .2 \\
\hline Overall Satisfaction & Excellent & 282 & 67.6 \\
& Good & 127 & 30.5 \\
& Fair & 7 & 1.7 \\
\hline
\end{tabular}

Table 2 presents the psychographic profile of the respondents. Most of the respondents agreed to visit Cagayan Valley Region Again with a bigger number of 337 or 80.8 percent as to compared with an undecided answer of "maybe" with 78 or 18.7 percent while the 2 or .5 percent implied "never" to visit the region. Most of the tourists agreed that given the chance to travel again, they will go and explore the place longer and farther, since there got a limited time and mobility because of pandemic issues. Very few said that they will never return because of some personal matter. They did not discuss any more to the researcher and it has nothing to do with place as they affirmed.

4 Consortia Academia Publishing (A Partner of Tourism Educators and Movers of the Philippines) 
The 355 or 85.1 percent respondents recommend the region, for maybe, 61 or 14.6 percent and never is only 1 or .2 percent. They will recommend the place to others, the respondents said that there is no reason at all not to recommend. The destination as whole is good destination specially for nature-based tourists. For overall satisfaction, it figured out that there were 282 or 67.6 percent of respondents excellently satisfied, many assess their satisfaction as good with 127 or 30.5 percent and the fair satisfaction of 7 or 1.7 percent, the least is 1 or .2 percent, poor satisfaction. Based on the interaction with the tourists, they are satisfied however, because of some travel restrictions and issues, they were not able to explore thoroughly the places. They added, when pandemic ends, the possibility to come back has greater chances and they will make sure that they are going to have the maximum value of their trip. They will visit the churches, cities, and other attractions in the area. The categorization of customers is an important aspect of religious tourism strategy. Researchers have difficult to distinguish between "pilgrims" and "tourists" since their identities overlap to a considerable extent while participating in religious activities/sightseeing (Wang et al., 2020).

Table 2

Assessment on the tourists' intention, motivation and experience

\begin{tabular}{|c|c|c|c|c|}
\hline & $\begin{array}{c}\text { Composite } \\
\text { Mean }\end{array}$ & $\begin{array}{c}\text { Standard } \\
\text { Deviation }\end{array}$ & Verbal Interpretation & Rank \\
\hline Social Environment & 4.62 & 0.57 & Strongly Agree & 2 \\
\hline Religious Sites Facilities & 4.55 & 0.61 & Strongly Agree & 4 \\
\hline Food and beverage & 4.49 & 0.71 & Agree & 5 \\
\hline Service Quality & 4.47 & 0.71 & Agree & 6 \\
\hline Locals' Behavior & 4.55 & 0.65 & Strongly Agree & 3 \\
\hline Religious site tourist's revisit intentions & 4.71 & 0.57 & Strongly Agree & 1 \\
\hline Behavior & 4.56 & 0.58 & Strongly Agree & \\
\hline Cultural and Historic Motives & 4.67 & 0.61 & Strongly Agree & 5 \\
\hline Spiritual and Religious Motives & 4.70 & 0.60 & Strongly Agree & 4 \\
\hline Fun and Social Contact & 4.73 & 0.60 & Strongly Agree & 2 \\
\hline Nature & 4.75 & 0.57 & Strongly Agree & 1 \\
\hline Wellness and Healing & 4.70 & 0.63 & Strongly Agree & 3 \\
\hline Motivation & 4.71 & 0.57 & Strongly Agree & \\
\hline Religious Attributes & 4.69 & 0.60 & Strongly Agree & 2 \\
\hline Emotional involvement & 4.68 & 0.62 & Strongly Agree & 3 \\
\hline Overall satisfaction & 4.72 & 0.61 & Strongly Agree & 1 \\
\hline Experience & 4.70 & 0.58 & Strongly Agree & \\
\hline
\end{tabular}

Table 2 shows the assessment on the tourist' intention, motivation and experience show that the respondents are strongly motivated with over-all composite mean of 4.71 ; followed by high satisfied experience (4.70) and with very positive intention to revisit the religious sites in Cagayan Valley Region (4.56). The tourists' intention to visit the religious site is at peak. Based on the initial interview to the respondents, the common reasons pertain to the attached nature attractions to the religious site. The nature compliments to the solemnity of the religious site, it adds to relaxing feelings, peaceful mind and helps pacifying the mental and emotional state being. Religious activities are common factor to influence the behavioral intention to visit the religious sites. Based on the study the use of eWOM has a relationship or effect to tourist revisiting intention to a religious destination. Moreover, the use of other promotional tool is useful to attract new visitors (Iriobe et al., 2019).

Meanwhile, the present food and beverage in the area is important but has less impact to the respondents. The respondents are looking into better product offerings and services. Furthermore, the tourism service quality of the region needs to improve more. The tourists would always want to value their money, time, and travel experience. Religion and religiosity influence norms, which in turn influence food consumption and production patterns. Secular and conservative groups are served by several specialist supermarkets businesses. In recent years, fast food businesses have begun to serve in religious settings (Heiman, et al., 2017). In terms of tourist motivation, nature is a strong determinant to attract the tourist to visit the place (4.75); next is fun and social contact (4.73) then, the wellness and healing ambience of the religious site (4.70). Meanwhile, other factors are the spiritual and religious motives (4.70) and cultural and historic motives of the respondents (4.67). Based on the results, the respondents have shown their enormous admiration to the old-fashioned structures of the 
Tao-Ing, R. C.

religious sites and the nature within the place. In addition, the respondents considered the cultural and historical attraction in Cagayan Valley Region. They express appreciation on how the region valued cultural and historical heritage.

The respondents are extremely attached to the nature of the Cagayan Valley Region. Needless to say, the majestic beauty of Batanes, more so, other religious sites are situated close to nature. That ambience made the religious sites remarkable to the perception of many tourist's visitors. Very few would say that the purpose of their travel is for wellness and the healing ambience of the religious site. However, majority visited the religious sites for spiritual purposes and exploring the nature that surrounded the place. The focus was on passengers' perspectives as a source of heritage attraction information and a foundation for tourism decision-making. Heritage attractions are displayed and promoted, especially if the cultural value of the attractions is emphasized. Furthermore, religious places should be investigated in tourism to see whether and how they might improve tourists' experiences (De Ascaniis et al., 2017).

\section{Table 3}

Significant difference on tourists' intention, motivation and experience when grouped according to satisfaction

\begin{tabular}{lccccc}
\hline & Excellent & Good & Z-value & p-value & Remarks \\
\hline Social Environment & 208.64 & 196.93 & -.991 & .322 & Not Significant \\
Religious Sites Facilities & 211.29 & 191.04 & -1.694 & .090 & Not Significant \\
Food and beverage & 210.45 & 192.91 & -1.487 & .137 & Not Significant \\
Service Quality & 210.88 & 191.94 & -1.617 & .106 & Not Significant \\
Locals' Behavior & 210.78 & 192.16 & -1.632 & .103 & Not Significant \\
Religious site tourist's revisit intentions & 211.64 & 190.26 & -2.068 & .039 & Significant \\
Behavior & 211.55 & 190.45 & -1.719 & .086 & Not Significant \\
\hline Cultural and Historic Motives & 213.41 & 186.31 & -2.594 & .009 & Significant \\
Spiritual and Religious Motives & 210.13 & 193.60 & -1.549 & .121 & Not Significant \\
Fun and Social Contact & 209.09 & 195.93 & -1.244 & .214 & Not Significant \\
Nature & 208.71 & 196.75 & -1.188 & .235 & Not Significant \\
Wellness and Healing & 209.12 & 195.85 & -1.314 & .189 & Not Significant \\
Motivation & 211.21 & 191.21 & -1.772 & .076 & Not Significant \\
\hline Religious Attributes & 207.49 & 199.47 & -.756 & .450 & Not Significant \\
Emotional involvement & 205.43 & 204.04 & -.132 & .895 & Not Significant \\
Overall satisfaction & 207.60 & 199.22 & -.782 & .434 & Not Significant \\
Experience & 207.20 & 200.12 & -.643 & .520 & Not Significant \\
\hline
\end{tabular}

There is no significant difference on the responses of Tourists' Intention, Motivation and Experience when they are grouped according to sex, age, civil status, purpose of visit, length of visit, willing to visit and recommend to others to come as denoted by the computed p-values of greater than 0.05 alpha level. This signifies that the tourists could have high or low Intention, Motivation and Experience in visiting Religious Sites in Cagayan Valley Region. Data on worship service attendance is available in 81 nations, according to Pew Research Center (2016), with an average of 48 percent of men and 42 percent of women reporting attending worship services at least once a week. The pattern of attendance, on the other hand, differs greatly amongst different nations. A distinct trend occurs among Christians. In the 53 nations having enough Christian respondents to examine data on attendance, $53 \%$ of Christian women and $46 \%$ of Christian men say they attend services at least once a week, a 7-percentage point difference. Furthermore, Christians of both genders are equally likely to attend church services on a regular basis.

This indicates that there is no significant difference exists on the responses of Tourists' Intention, Motivation and Experience when they are grouped according to overall satisfaction as denoted by the computed p-values of greater than 0.05 alpha level except for religious site tourist's revisit intentions $(z=-2.068, p=0.039)$ and Cultural and Historic Motives $(z=-2.594, p=.009)$. This signifies that those with excellent satisfaction on religious site tourist's revisit intentions and Cultural and Historic Motives could have higher Intention, Motivation and Experience in visiting Religious Sites in Cagayan Valley Region than those tourists with good rating on their overall satisfaction. Based on the result, it implies that the respondents are satisfied from what they have experienced in the religious sites. As a result, they are rich in history and cultural legacy, which encourages

6 Consortia Academia Publishing (A Partner of Tourism Educators and Movers of the Philippines) 
cultural aficionados to participate. Cultural enthusiasts, on the other hand, do not always begin on a religious level (Wang et al., 2020). In terms of cultural and historic motives, the tourists were motivated to visit the region since the place showcased many famous historical ruins, archeological sites, and reserved Cagayan ethnic groups. Their museums displayed with many repository artifacts of early civilization in the region. Chinese dynasties porcelain pieces are also displayed while, many old churches are also significant in the destinations since these has many foretold historical stories during the Spanish era. The ruins and old structures extensively still stand beautifully for many years. The destination became active and create competitive status in the tourism marketplace. The distinctiveness of the place set a promising destination image in the face of tourism industry (Organization for economic Co-operative and Development 2009; Nilsson, 2018).

\section{Table 4}

Significant relationship of experience between tourists' intention and motivation

\begin{tabular}{|c|c|c|c|c|c|c|c|c|c|}
\hline \multirow{2}{*}{\multicolumn{2}{|c|}{$\begin{array}{l}\text { Tourists' } \\
\text { Intention }\end{array}$}} & \multicolumn{5}{|c|}{ Motivation } & \multicolumn{3}{|c|}{ Experience } \\
\hline & & CHM & SRM & FSC & $\mathrm{N}$ & $\mathrm{WH}$ & RA & EI & $\mathrm{OS}$ \\
\hline \multirow[t]{3}{*}{$\mathrm{SE}$} & $\mathrm{r}_{\mathrm{s}}$-value & $.675(* *)$ & $.703(* *)$ & $.640(* *)$ & $.685(* *)$ & $.654(* *)$ & $.688(* *)$ & $.678(* *)$ & $.775(* *)$ \\
\hline & alue & 0 & 0 & 0 & 0 & 0 & 0 & 0 & 0 \\
\hline & Remarks & $\begin{array}{l}\text { Significant } \\
621(* *)\end{array}$ & Significant & Significant & Significant & Significant & Significant & Significant & ignificant \\
\hline RSF & & 0 & 0 & 0 & $\begin{array}{c}.007 \\
0\end{array}$ & 0 & $\begin{array}{c}0 \\
0\end{array}$ & $\begin{array}{r}.070 \\
0\end{array}$ & $\begin{array}{c}0 \\
0\end{array}$ \\
\hline FB & $\begin{array}{l}\text { Remarks } \\
\mathrm{r}_{\mathrm{s}} \text {-value } \\
\mathrm{p} \text {-value }\end{array}$ & $\begin{array}{c}\text { Significant } \\
.635(* *) \\
0\end{array}$ & $\begin{array}{c}\text { Significant } \\
.648(* *) \\
0\end{array}$ & $\begin{array}{c}\text { Significant } \\
.599(* *) \\
0\end{array}$ & $\begin{array}{c}\text { Significant } \\
.642(* *) \\
0\end{array}$ & $\begin{array}{c}\text { Significant } \\
.563(* *) \\
0\end{array}$ & $\begin{array}{c}\text { Significant } \\
.583(* *) \\
0\end{array}$ & $\begin{array}{c}\text { Significant } \\
.593(* *) \\
0\end{array}$ & $\begin{array}{c}\text { Significant } \\
.648(* *) \\
0\end{array}$ \\
\hline SQ & $\begin{array}{l}\text { Remarks } \\
\mathrm{r}_{\mathrm{s}} \text {-value } \\
\mathrm{p} \text {-value }\end{array}$ & $\begin{array}{c}\text { Significant } \\
.639(* *) \\
0\end{array}$ & $\begin{array}{c}\text { Significant } \\
.685(* *) \\
0\end{array}$ & $\begin{array}{c}\text { Significant } \\
.576(* *) \\
0\end{array}$ & $\begin{array}{c}\text { Significant } \\
.611(* *) \\
0\end{array}$ & $\begin{array}{c}\text { Significant } \\
.581(* *) \\
0\end{array}$ & $\begin{array}{c}\text { Significant } \\
.635(* *) \\
0\end{array}$ & $\begin{array}{c}\text { Significant } \\
.660(* *)\end{array}$ & $\begin{array}{c}\text { Significant } \\
.716(* *) \\
0\end{array}$ \\
\hline LB & $\begin{array}{l}\text { Remarks } \\
\text { rs}_{\text {s-value }} \\
\text { p-value }\end{array}$ & $\begin{array}{c}\text { Significant } \\
.598(* *) \\
0\end{array}$ & $\begin{array}{c}\text { Significant } \\
.677(* *) \\
0\end{array}$ & $\begin{array}{c}\text { Significant } \\
.576(* *) \\
0\end{array}$ & $\begin{array}{c}\text { Significant } \\
.635(* *) \\
0\end{array}$ & $\begin{array}{c}\text { Significant } \\
.589(* *) \\
0\end{array}$ & $\begin{array}{c}\text { Significant } \\
.647(* *) \\
0\end{array}$ & $\begin{array}{c}\text { Significant } \\
.611(* *) \\
0\end{array}$ & $\begin{array}{c}\text { Significant } \\
.672(* *) \\
0\end{array}$ \\
\hline \multirow[t]{2}{*}{ RI } & $\begin{array}{l}\text { Remarks } \\
\mathrm{r}_{\mathrm{s}} \text {-value } \\
\mathrm{p} \text {-value }\end{array}$ & $\begin{array}{c}\text { Significant } \\
.716(* *) \\
0\end{array}$ & $\begin{array}{c}\text { Significant } \\
.738(* *) \\
0\end{array}$ & $\begin{array}{c}\text { Significant } \\
.642(* *) \\
0\end{array}$ & $\begin{array}{c}\text { Significant } \\
.633(* *) \\
0\end{array}$ & $\begin{array}{c}\text { Significant } \\
.670(* *) \\
0\end{array}$ & $\begin{array}{c}\text { Significant } \\
.639(* *) \\
0\end{array}$ & $\begin{array}{c}\text { Significant } \\
.603(* *) \\
0\end{array}$ & $\begin{array}{c}\text { Significant } \\
.744(* *) \\
0\end{array}$ \\
\hline & \multicolumn{8}{|c|}{ Experience } & Significant \\
\hline \multirow[t]{3}{*}{ RA } & $\mathrm{r}_{\mathrm{s}}$-value & $.664(* *)$ & $.727(* *)$ & $.769(* *)$ & $.763(* *)$ & $.776(* *)$ & 1 & $.869(* *)$ & $.868(* *)$ \\
\hline & & 0 & 0 & 0 & 0 & 0 & - & 0 & 0 \\
\hline & $\begin{array}{l}\text { Remarks } \\
\mathrm{r}_{\mathrm{s}} \text {-value }\end{array}$ & $\begin{array}{c}\text { Significant } \\
.653(* *)\end{array}$ & $\begin{array}{c}\text { Significant } \\
.767(* *)\end{array}$ & $\begin{array}{c}\text { Significant } \\
.814(* *)\end{array}$ & $\begin{array}{c}\text { Significant } \\
.817(* *)\end{array}$ & $\begin{array}{c}\text { Significant } \\
.846(* *)\end{array}$ & $.869(* *)$ & $\begin{array}{c}\text { Significant } \\
1\end{array}$ & $\begin{array}{c}\text { Significant } \\
.859(* *)\end{array}$ \\
\hline \multirow{2}{*}{ EI } & p-value & 0 & 0 & 0 & 0 & 0 & 0 & . & 0 \\
\hline & $\begin{array}{l}\text { Remarks } \\
\mathrm{r}_{\mathrm{s}} \text {-value }\end{array}$ & $\begin{array}{c}\text { Significant } \\
.757(* *)\end{array}$ & $\begin{array}{c}\text { Significant } \\
.745(* *)\end{array}$ & $\begin{array}{c}\text { Significant } \\
.734(* *)\end{array}$ & $\begin{array}{c}\text { Significant } \\
.775(* *)\end{array}$ & $\begin{array}{c}\text { Significant } \\
.782(* *)\end{array}$ & $\begin{array}{c}\text { Significant } \\
.868(* *)\end{array}$ & $.859(* *)$ & $\begin{array}{c}\text { Significant } \\
1\end{array}$ \\
\hline \multirow{2}{*}{ OS } & & 0 & 0 & 0 & 0 & 0 & 0 & 0 & - \\
\hline & Remarks & Significant & Significant & Significant & Significant & Significant & Significant & Significant & \\
\hline
\end{tabular}

High significant positive relationship exists on Tourist Experiences Visiting Religious Sites in Cagayan Valley Region between Tourist Motivation and Tourist intention as denoted by the computed p-values of less than 0.05 alpha level. This signifies that those tourists with higher level of tourist motivation and tourist intention are also those tourists with higher level of tourist experience. Based on the findings, the tourist intention is relevant to what motivates them visiting the religious sites, upon visiting they experience beyond religious activities. Region II has many to offer to the tourist, the adorable landscape and magnificent seascape, stories behind each wall of the old structures of the churches including the religious relics. Because of its distinctive characteristics, such as the seven-chambered cave with gorgeous limestone rock formations evocative of a cathedral dome, the Callao Cave in Tuguegarao City, Cagayan Valley, is one of the most popular and attractive attractions. A stone altar lighted by a natural skylight may be seen in one of the chambers at this Tuguegarao tourist attraction. There's also the cave where millions of bats live, a cave where many red-billed hornbills can be seen, and a cave where the Basilica Minore of Our Lady of Piat may be found.

The Callao Cave is another one of the historical Cagayan Valley locations, as is the Tuguegarao Cathedral, commonly known as St. Peter's Cathedral. It houses the Archdiocese of Tuguegarao City Cagayan Valley and is 
the province's largest Spanish-style church. The large complex of this Tuguegarao tourist attraction is a fantastic place to think or meditate. The nature that embraces in each province is overwhelming that makes the tourists amaze. With this beautiful nature, the tourist can do hiking, swimming, caving, visit lighthouses and island hopping. Such features of Region II intensify the intention and motivation of the tourist. After which they go home with many memories to cherish. Therefore, as it examines the tourists' intention, motivation and satisfaction while taking part in a re in religious sites tour in Region II, it entails gaining a knowledge of visitors' experiences and behaviors while they participate in various activities at various sites. The tourists experience they've had and the primary characteristics they're looking for in a place. It also emphasizes the significance of these characteristics in their experience and passion. As a result, there is a link between visitors' intentions, motivation, the activities they participate in visiting religious places, and their overall satisfaction level.

The tourism industry's problem is to be aware of what tourists want and to respond appropriately. The factors that go into the complicated interplay between visitors' intentions, motivation, and fulfillment. The personal and intrinsic motives of an individual are centered on finding a location to rest, socialize, contemplate, meditate, and enjoy personal relationships. Based on the test, motivation and experience is relevant to the tourist intention and behavior like for instance in the between social environment to cultural and historic motives. The two are connected since both pertain to the religious sacredness of the site, the tourists are motivated to visit the site as they are interest and enjoyed the authentic religious experiences. On the other hand, tourists are much interest to perform spiritual activities there in the religious sites; they do self-reflection, discover historical data attached to the religious relics and to the old structures as well, and feel the sacredness of the place where they could also feel the closeness to the nature. The nature compliments or intensify the feelings of being close to God and to nature as well. So much fun and social contact that would give the tourists the opportunity to spend time with locals. Tourists and local community engagement would give them both additional memorable experience. Meanwhile, the social environment of Cagayan Valley Region could be of help to sustain the wellness and healing atmosphere of the religious sites where the visitors comfortable to travel around the place, they could pray quietly without thinking that would take advantage their busyness. Therefore, the social environment is important soothing the entire religious travel experience of the tourist around the Cagayan Valley Region.

Overall satisfaction was shown to be significantly influenced by travel motivations. In addition, the direct impacts of pull travel incentive on return intention and readiness to suggest were discovered. Overall satisfaction, on the other hand, affected revisit intention more than readiness to suggest. The links between travel goals and return intention were also somewhat mediated by overall pleasure. the direct and indirect impacts of motives on the behavioral intentions of domestic tourists in the construction of a domestic tourism behavioral model, and the linkages between motivations, satisfaction, and behavioral intentions to revisit and willingness to suggest (Bayih \& Singh, 2020). Tourists' Expectations for Visiting Historical Sites, most respondents have high transportation expectations. There is a substantial association, which suggests that the better the experience, the greater the level of motivations, the higher the anticipation, and the higher the degree of experience ( $\mathrm{Li} \&$ Borbon, 2021).

In the context of religious attributes, emotional involvement and the overall satisfaction could really give a great impact on the social environment. The religious attributes are well-preserved and highly valued, able to maintain authenticity of the religious architectures until this time. Thus, it reflects to the satisfaction, and emotional involvement of the tourists to the religious sites and other tourist destinations in Cagayan Valley Region. Furthermore, the tourist intention to visit the place because of the experiences of tourists is very positive on that note that religious sites are accessible, they able to express their spiritual acts, manners, and efforts, they enjoyed the nature and engaged with the local people as well. The facilities, transportation and other tourists' activities within the region obtained good impression.

Understanding the reasons and experiences of tourists that impact the performance of historical sites is critical for improved management of the site in accordance with visitor needs and expectations (Li \& Borbon, 2021) Theoretical and empirical findings relating to travel motivation, satisfaction, perceived value, and

8 Consortia Academia Publishing (A Partner of Tourism Educators and Movers of the Philippines) 
recommendation. An integrated model that combined motivation, satisfaction, and perceived value into the greater area of tourist behavior was experimentally evaluated. The data reveal that perceived value and pleasure have a bigger impact on recommendation than motivation. Furthermore, the findings show that motivation may be utilized as a predictor of recommendation, as indicated (Huang et al., 2015).

In terms of relationship between tourist experiences and cultural and historic motives, the two are closely relevant to each other since the motives directly impacted many factors to the tourists to travel then experience the place of the destination. The cultural and historic content are important as they serve as the main drivers to attract tourists. Its facilities, ambience, accessibility, physical environment, and the locals as well. While the spiritual and religious motives is also relevant to the tourist experience, these motives influenced the tourist behavior and experience. Their intention to have a spiritual engagement to God in a sacred place like what can be found in Cagayan Valley Region is something being investigated by many tourists to explore, enjoy and satisfactorily experienced. More so, the nature, local community and tourist activities are also parts of the meaningful tourist and local experiences. The attractions' qualities and the overall image of the destination have a favorable association, extending a substantial relationship to the tourist experience and therefore having emotional impacts on tourist intention and behavior to return to the location (Hung et al., 2021). Furthermore, more the indirect association between tourist image and the intention to return through tourism experiential fulfillment, on the other hand, has a positive value (Rini et al., 2021).

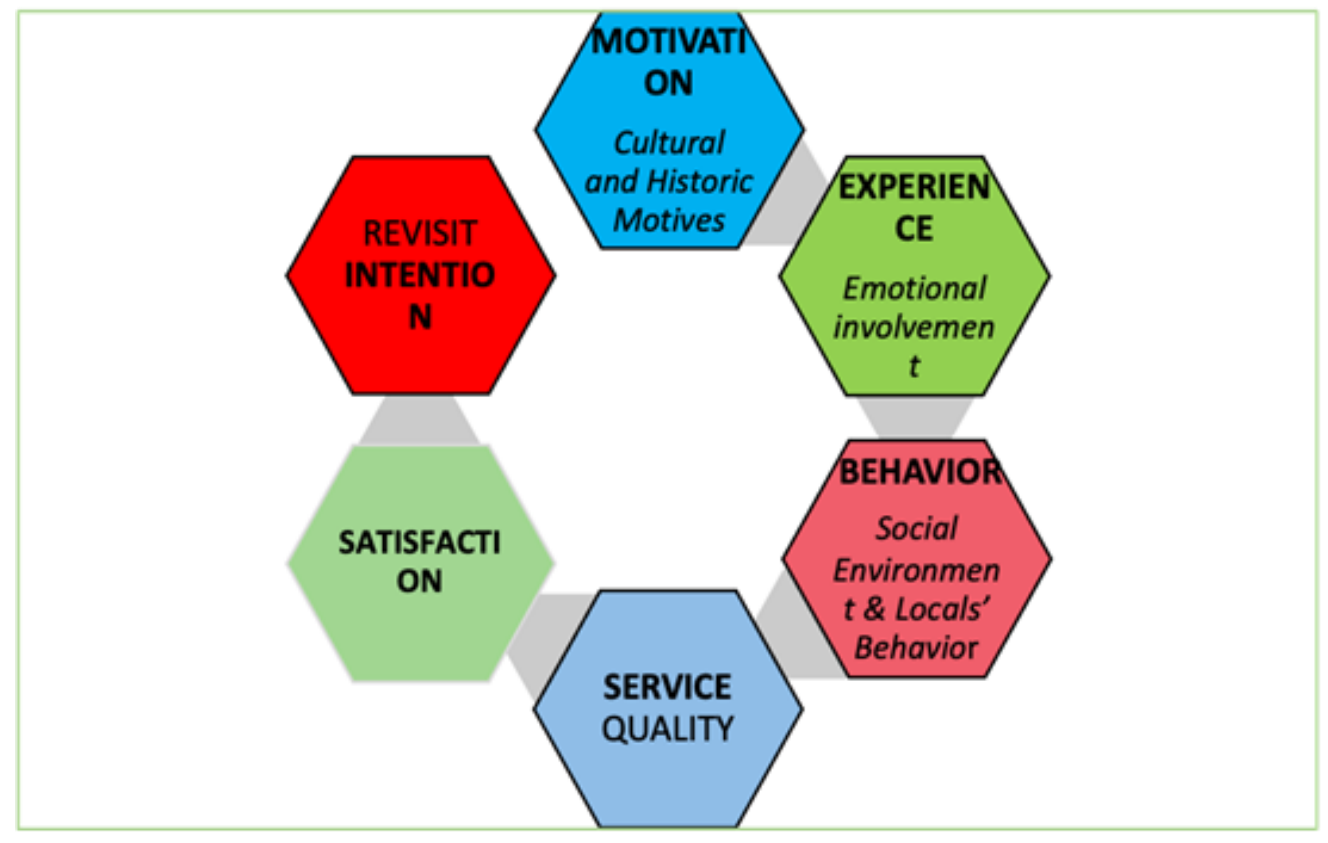

Figure 1. Proposed framework for religious sites improvement in Cagayan Valley Region

\section{Model Description}

The three main variables: tourist motivation, experience and revisit intention are significantly relevant to their respective sub-variables, the arrows connect them convey direct relationship to each other. These three main variables are the primary content focus' for proposed framework for the development of religious sites in Cagayan Valley Region. Meanwhile, the sub-variables are the influences or affecting factors for a great change or innovation to sustain the religious sites situated in Cagayan Valley Region. For instance, the tourist motivation on cultural and historical is most valued therefore, effective provisions of preservation and restoration of religious sites in Cagayan Valley Region must be strengthen. Community awareness and involvement may be another important factor to sustain the cultural and historical preservation and secure the quality service rendered to the tourists. 
Furthermore, in terms of tourist experience, the emotional involvement of the tourists to the destination is extremely important that may be used as the basis for the improvement of the religious sites and its dimensions in Cagayan Valley Region. Facilities and amenities of the destination will compliment to the meaningfulness of the travel within the Cagayan Valley Region. These must be heightened and emphasized specifically the food and beverage sector since this was the least favored experience of majority of the tourists in Cagayan Valley Region. Tourists love to experience local cuisine and products thus; this area may be improved to gain strong and positive involvement of the tourists while visiting the destinations within Cagayan Region. In this case, tourist satisfaction is enormously possible.

Lastly, based on the result of the study, the revisit intention to religious sites in Cagayan Valley Region was greatly affected by the social environment and local's behavior. For that instance, these areas may be strengthened through providing the local with relevant trainings to become effective, well rounded and enthusiastic front liners in the tourism industry of each province in Cagayan Valley Region, thus, Creating more job and business opportunities among the locals. If they are equipped, happy and well privileged it will reflect on their satisfying service performance in the tourism service community for the entire Cagayan Valley Region.

The researcher believed that measuring the performance of Cagayan Valley Region is an urgent and meaningful work for religious site improvement. This new framework will help to strengthen the provisions for the preservation and conservation of the many religious sites in the said region. The inputs placed on this research paper may be used as the baseline for the sustainable development or enhancement of the entire Cagayan Valley Region as to become the most remarkable religious destination in Luzon.

Therefore, the motivation, satisfaction and behavioral intention of tourist may vary in different phases in relation with intervening effect of the religious destination. Another note that religious sites may consider for economic growth of the destinations, are broader social senses and ecological environments, and obtaining successful holistic performance in the tourism industry of Cagayan Valley Region.

\section{Conclusion and Recommendation}

Majority of the respondents are female, 25 years old and below, generation $\mathrm{Z}$ and single. Most of the respondents visited Cagayan Valley Region because they wanted to discover new cultures and different religions and stayed for 2-4 days. They confirmed that they will visit again the region and recommend it to others because they are excellently satisfied. Based on the result, tourists' revisit the religious sites in Cagayan Valley Region in terms of social environment is because of the sacredness of the ambience, for facilities the respondents look in to the availability and accessibility of the prayer area. Further, the respondents affirmed the presence of clean and safe food establishments, staff in the religious area are friendly, can communicate well and respectful that made them satisfied to visit other religious sites in Cagayan Valley region in the future. The research study showed the relevance of tourist motivation visiting the religious sites in Cagayan Valley Region focused on the interest to religious figures, love, and respect for God, spend time with their family and friend while on a trip enjoying the beautiful landscape and nature and believed that travelling to religious site relieved stress and harmonized emotions. The study looked further also on the tourist experiences on visiting the religious sites in Cagayan Valley Region, the respondents affirmed that the religious sites are well conserved, emotionally, the destination is special to them which gave them a happy feeling. There is no significant difference on tourist' intention, motivation and experience when grouped according to the profile variables however, on the psychographic profile which specifically refers to the overall satisfaction. There is a significant difference on religious site tourist's revisit intentions and cultural and historic motives. On the other hand, there is a significant relationship of experience between tourist's intention and motivation. The researcher proposed a framework for religious sites improvement in Cagayan Valley Region. 


\section{References}

Apritado, J. M., \& Borbon, N. M. (2021). Expectations and experiences of tourists on attractions in Batangas Province. International Journal of Research Studies in Education, 10(1), 13-22. https://doi.org/10.5861/ijrse.2020.5918

Aulet, S., \& Duda, T. (2020). Tourism accessibility and its impact on the spiritual sustainability of sacred sites. Sustainability, 12, 9695. https://doi.org/10.3390/su12229695

Bayih, B. E., \& Singh, A. (2020). Modeling domestic tourism: motivations, satisfaction and tourist behavioral intentions. Heliyon, 6(9), e04839. https://doi.org/10.1016/j.heliyon.2020.e04

Blackwell, R. (2011). Motivation for pilgrimage: Using theory to explore motivations. Pilgrimages Today, 24-37.

De Ascaniis, S., \& Cantoni, L. (2017). Online visit opinions about attractions of the religious heritage: anargumentative approach. Church, Communication and Culture, 2(2), 179-202. https://doi.org/10.1080/23753234.2017.1350

Duda, T., \& Doburzyński, D. (2019). Religious tourism vs. sacred space experience: Conflict or complementary interaction? International Journal of Religious Tourism and Pilgrimage, 7(5), 1-10.

Giușcă, G., \& Dumitrache. (2018). Assessment of the religious- tourism potential in Romania. Human Geographies, 12(2), 225-237. https://doi.org/10.5719/hgeo.2018.122.6

Hanafiah, M. H., Maek, A. A., \& Zahari, M. S. M. (2021). Muslim tourist behavior and intention to revisit non-Muslim countries: The role of Muslim-Friendly Tourism (MFT) attributes. International Journal of Religious Tourism and Pilgrimage, 9(1), 14. https://arrow.tudublin.ie/ijrtp/vol9/iss1/14

Huang, S., Shen, Y., \& Choi, C. (2015). The effects of motivation, satisfaction and perceived value on tourist recommendation. https://scholarworks.umass.edu/ttra/ttra2015/Student_Colloquium/5

Hung,V. V., Dey, S. K., Vaculcikova, Z., \& Anh, L. T. H. (2021). The influence of tourists' experience on destination loyalty: A case study of Hue City, Vietnam. Sustainability, 13, 8889. https://doi.org/10.3390/su13168889

Iriobe, O. C., \& Abiola-Oke, E. O. (2019). Moderating effect of the use of eWOM on subjective norms, behavioural control and religious tourist revisit intention. International Journal of Religious Tourism and Pilgrimage, 7(3).

Li, C., \& Borbon, N. M. (2021). Tourists' motives, expectation and experience to historical sites in hunan province. International Journal of Research Studies in Management, 9(3), 15-24. https://doi.org/10.5861/ijrsm.2021.m7724

Muriuki, L. M., Bururia, D., \& Mutegi, J. (2016). Determinants of religious tourism branding tactics in Kenya: A cross sectional study. Tourism and Hospitality Research. https://doi.org/10.1177/1467358416670937

NEDA. (2013). Cagayan valley Regional Development Plan, 2011-2016. Retrieved from https://www.neda.gov.ph/wp-content/uploads/2013/10/RegII_RDP_2011-2016.pdf

Nicolaides, A., (2016). Marian Tourism: Eastern Orthodox and Roman Catholic pilgrimage. African Journal of Hospitality, Tourism and Leisure, 5(4). http://hdl.handle.net/10500/22737

Nieminen, K. (2012). Religious Tourism - a Finnish Perspective. (Thesis, University of Applied Science).

Nilsson, P. A. (2018). Impact of cultural heritage on tourist: The heritagization process. Athens Journal of Tourism, 5(1), 35-54. https://www.athensjournals.gr/tourism/2018-5-1-3-Nilsson.pdf

Olsen, D. H. (2019). Pilgrimage and tourism to holy cities: Ideological and management perspectives. Journal of Heritage Tourism, 14, 581-582. https://doi.org/10.1080/1743873X.2018.1556833

Organization for Economic Co-operation and Development. (2009). Impact of Culture on Tourism. Retrieved from https://www.oecd.org/cfe/tourism/theimpactofcultureontourism.htm

Pew Research Center. (2016). Gender differences in worship attendance vary across religious groups. Retrieved from https://www.pewforum.org/

Rebuya, N., Lasarte, E., Amador, M., \& De la Roca, G. (2020). Assessing religious tourism motivational factors and experiences of visitors to selected religious sites in Camarines Sur, Philippines. Open Access Library Journal, 7, 1-10. https://doi.org/10.4236/oalib.1106404 
Tao-Ing, R. C.

Rini, E. S., Absah, Y., Sembiring, B. K. F., \& Nasution, M. D. T. P. (2021). Intention to revisit tourist destinations in Indonesia. Innovative Marketing, 17(4), 37-48.

https://doi.org/10.21511/im.17(4).2021.04

Rybina, L., \& Lee, T. J. (2021). Traveler motivation and destination loyalty: Visiting sacred places in Central Asia. Tour. Hosp., 2, 1-14. https://doi.org/10.3390/tourhosp 2010001

Shen, K., Geng, \& Su, X. (2019). Antecedents of residents' pro-tourism behavioral intention: Place image, place attachment, and attitude. Frontiers in Psychology, 10(2349). https://doi.org/10.3389/fpsyg.2019.02349

Siedlecki, S. L. (2020). Understanding descriptive research designs and methods. https://doi.org/10.1097/NUR.0000000000000493

Wang, K. Y., Kasim, A., \& Yu, J. (2020). Religious festival marketing: Distinguishing between devout believers and tourists. Religions, 11(8), 413. https://doi.org/10.3390/rel11080413 